\title{
Genetic diversity and population dynamics of cyanophage communities in the Chesapeake Bay
}

\author{
Kui Wang, Feng Chen* \\ Center of Marine Biotechnology, University of Maryland Biotechnology Institute, 701 East Pratt Street, Suite 266, Baltimore, \\ Maryland 21202, USA
}

\begin{abstract}
In order to understand the genetic diversity and population dynamics of cyanophages in estuarine waters, the viral capsid assembly (g20) gene was used as a gene marker to monitor genetic variations of natural cyanomyovirus communities in the Chesapeake Bay, USA. Unique and diverse g20 sequences were found. Only 1 of 15 g20 genotypes was closely related to the known cyanomyovirus isolates. Most of the g20 genotypes in the bay were not related to the $\mathrm{g} 20 \mathrm{clonal}$ sequences recovered from open-ocean waters. Terminal-restriction fragment length polymorphism (T-RFLP) based on the g20 gene was developed to investigate spatial and temporal distribution of cyanomyovirus communities in the bay. The T-RFLP profiles of the g20 gene demonstrated that the cyanomyovirus population structures in the bay were more dynamic seasonally than spatially. Seasonal variation in the cyanophage community appeared to correspond to changes in host-cell density, which in turn was mainly affected by water temperature. This study represents the first effort to monitor both cyanophage titer and genetic diversity over time and space. The results of our study suggest that cyanophages could play a significant role in regulating Synechococcus biomass and population structure in the Chesapeake Bay.
\end{abstract}

KEY WORDS: Cyanophage $\cdot$ Synechococcus $\cdot$ Natural virus community $\cdot$ Phylogenetic diversity $\cdot$ T-RFLP

\section{INTRODUCTION}

Discovery of highly abundant viruses (i.e. $10^{7}$ viral particles $\mathrm{ml}^{-1}$ ) in marine environments re-initiated investigation into the ecological roles of marine viruses (Bergh et al. 1989, Proctor \& Fuhrman 1990, Fuhrman 1999). Viruses are now known to be ubiquitous biological components that could regulate element cycling in the microbial loop, altering the nutrient cycling and energy flow (Suttle et al. 1990, Fuhrman \& Suttle 1993, Thingstad et al. 1993, Bratbak et al. 1994, Wilhelm \& Suttle 1999). Viruses are also thought to mediate gene transfer among microorganisms in natural aquatic environments, and shape the genetic diversity of the microbial community by means of virus-mediated genetic exchange such as transduction, transformation and conversion between lytic and lysogenic cycles (Fuhrman 1999, Paul 1999, Wommack \& Colwell 2000). Unicellular cyanobacteria of the genus Synechococcus are among the most abundant and ubiquitous mem- bers of the picoplankton in the open ocean, where it has been estimated that they are responsible for up to $25 \%$ of the primary production (Waterbury et al. 1986, Li 1994). Cyanophages were found to be abundant (i.e. $10^{3}$ to $10^{6} \mathrm{ml}^{-1}$ ) and a significant factor in determining the dynamics of Synechococcus populations (Suttle \& Chan 1993, 1994, Waterbury \& Valois 1993, Wilson et al. 1993, Lu et al. 2001). Cyanophages that infect Synechococcus spp. can sometimes reach concentrations in excess of $10^{6} \mathrm{ml}^{-1}$ in marine environments (Suttle \& Chan 1994, Suttle 2000).

Cyanophage isolates that infect marine Synechococcus spp. are diverse in terms of morphology. All known cyanophages belong to 3 phage families, Myoviridae, Podoviridae and Siphoviridae (Safferman et al. 1983, Ackermann \& DuBow 1987, Martin \& Benson 1988). Molecular characterization of natural cyanophage assemblages has so far revealed much greater diversity than expected. Cyanophage genotypes revealed by restriction fragment length polymorphism (RFLP) 
exhibited even greater complexity than their morphotypes (Wilson et al. 1993, Lu et al. 2001). Cyanophages of Myoviridae (cyanomyoviruses) are commonly found among cyanophage isolates (Suttle \& Chan 1993, Waterbury \& Valois 1993, Lu et al. 2001). Characterization of a conserved viral capsid assembly protein gene (g20) in 3 cyanomyoviruses allowed the design of PCR primers specific to cyanomyoviruses, and therefore greatly facilitated the investigation of genetic diversity of natural cyanophage assemblages (Fuller et al. 1998). Recently, denaturing gradient gel electrophoresis (DGGE) analysis based on 165 bp DNA fragments of the g20 gene amplified by cyanomyovirus-specific PCR primers (CPS4 and CPS5) has been used to examine the population structure of cyanophages along a south-north transect in the Atlantic Ocean. High genetic diversity of cyanophage was found throughout the depth profile, significant changes in the population structure were observed from surface to depth, and maximum diversity was always correlated to maximum Synechococcus abundances (Wilson et al. 1999, 2000). More recently, cyanomyovirus-specific primers (CPS1 and CPS8) have been successfully used to amplify ca. $592 \mathrm{bp}$ fragments of the g20 gene from many cyanomyovirus isolates and natural virus communities (Zhong et al. 2002). Phylogenetic analysis of 114 g20 gene sequences recovered from both coastal and oceanic water samples also revealed strikingly high genetic diversity. The g20 sequence diversity varied from coastal to oceanic waters and from surface water to the depth of the deep chlorophyll maximum (Zhong et al. 2002).

Genetic diversity in natural marine virus communities appears to be more complex than was expected. In order to better understand co-variation and co-evolution between marine phages and their host bacteria, it is necessary to study genetic variation among marine viruses. Microbial diversity studies based on cloning and sequencing techniques are expensive and timeconsuming, and are not suitable when a large amount of environmental samples are involved. Virioplankton communities in the Chesapeake Bay revealed by pulse-field gel electrophoresis (PFGE) demonstrated that annual variation in viral community structure was correlated with time, geographical location and extent of water-column stratification (Wommack et al. 1999a,b). A technique such as PFGE is very useful for large-scale ecological studies involving numerous environmental samples; however, it is more suitable for studying a viral community as a whole, rather than a specific group of phages such as cyanophages.

Currently, 2 rapid genetic fingerprinting techniques, DGGE (Muyzer et al. 1993, Muyzer 2000) and terminal-restriction fragment length polymorphism (TRFLP) (Liu et al. 1997, Marsh 1999) are commonly used to investigate complex microbial communities. The TRFLP method takes advantage of the high resolution and high throughput of automated sequencing technologies to detect terminal restriction fragments (TRFs) after restriction digestion. This method was first used to identify complex bacterial communities in 1994 (Avaniss-Aghajani et al. 1994), and since then it has been widely used to investigate complex community structure of bacterial, archaeal and eukaryal communities in various environments (Muyzer 2000). Compared with PCR-DGGE fingerprinting technique, the T-RFLP method can provide simple and rapid T-RF data using standard sequencing equipment, and these data are easily analyzed with a variety of statistical techniques. Comparison of observed with simulated TRFs from clone library or sequence database allows identification of specific genotypes. The use of DGGE, however, allows the subsequent sequencing of specific genotypes present in the gel, which is not possible with the T-RFLP technique. T-RFLP has been demonstrated to be an automated and sensitive tool for characterization of complex microbial community structure and dynamics (Liu et al. 1997, Marsh 1999, Muyzer 2000, Osborn et al. 2000, Kitts 2001).

In this study, we first examined the genetic diversity of cyanomyovirus in the Chesapeake Bay based on g20 gene RFLP patterns and their sequences. Secondly, the T-RFLP method based on the g20 gene was developed to investigate spatial and temporal variations of the natural cyanomyovirus population in the bay.

\section{MATERIALS AND METHODS}

Location and sampling. For spatial analysis, Chesapeake Bay water samples were collected using Niskin bottles from on board the R/V 'Cape Henlopen' from November 1 to 3, 2000. Water samples were collected from Pier 5 in the Baltimore Inner Harbor and from 3 stations (Stns 908, 818 and 707) in the Chesapeake Bay (Fig. 1 \& Table 1). For temporal analysis, water samples were collected monthly from Pier 5 in the Inner Harbor from March 2001 through May 2002. For direct counts of viruses and cyanobacteria, $10 \mathrm{ml}$ of surface water sample was collected from Pier 5, fixed with glutaraldehyde (final concentration of $2.5 \%$ ), and stored at $4^{\circ} \mathrm{C}$ in the dark until use.

Ultrafiltration. Viral communities from the bay were concentrated during the cruise, while viral concentrates (VCs) from the Inner Harbor were prepared in the laboratory. Viral communities were concentrated using the ultrafiltration protocols described by Chen et al. (1996). Briefly, 40 to $80 \mathrm{l}$ of water was filtered through A/E glass-fiber filters (Gelman Sciences; nominal pore size $1.2 \mu \mathrm{m}$ ) and $0.45 \mu \mathrm{m}$ pore-size low-pro- 


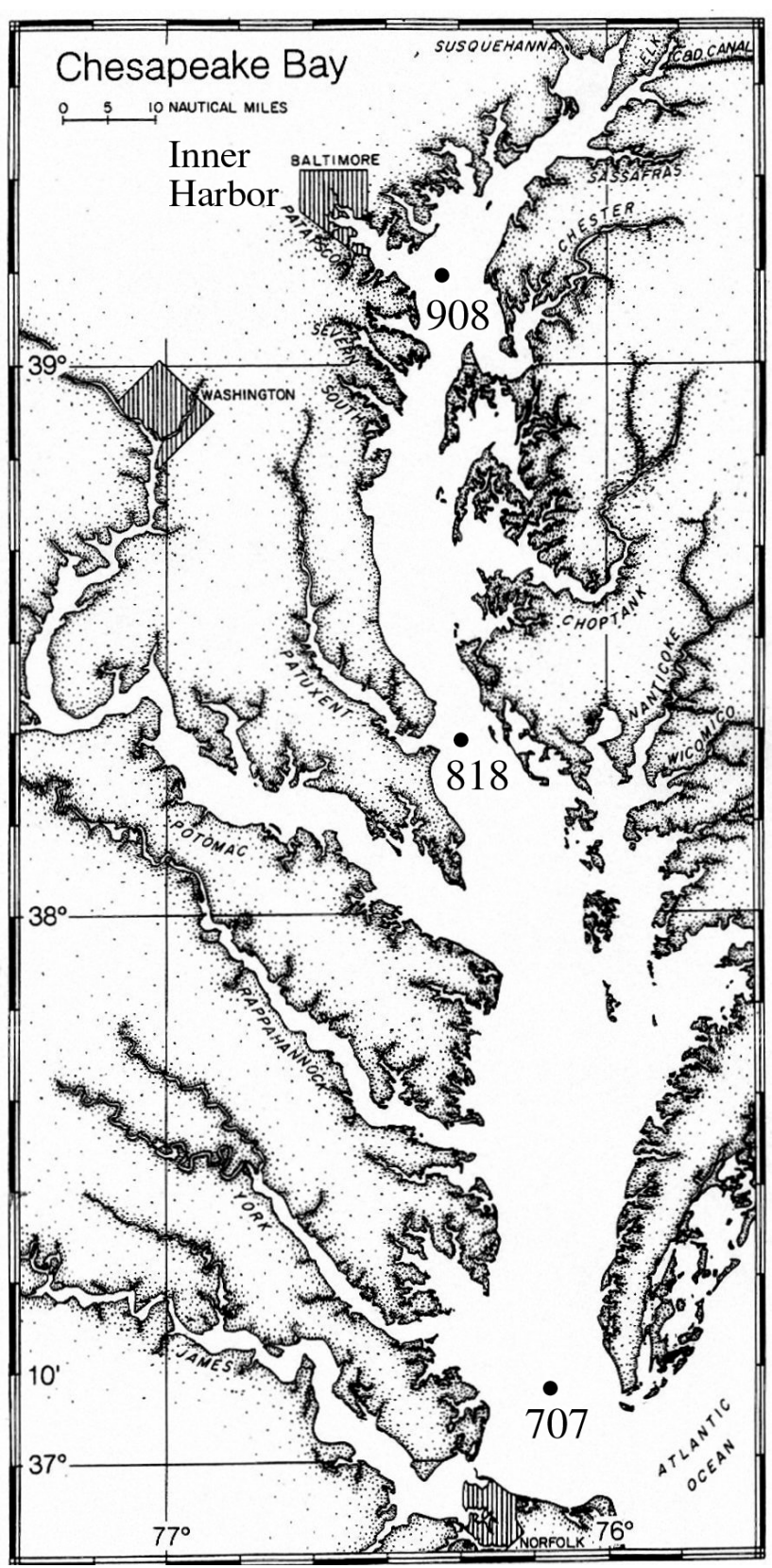

Fig. 1. Sampling sites in Chesapeake Bay, USA tein-binding Durapore membranes (Millipore). The filtrate was then concentrated by ultrafiltration through a 30000 MW cutoff Amicon S10Y30 spiral cartridge (Millipore) in the ProFlux M-12 system (Millipore), at $30 \%$ pump speed and 16 to $18 \mathrm{kPa}$ backpressure. The final water sample concentrates contained particulates ranging in size between $2 \mathrm{~nm}$ to $450 \mathrm{~nm}$ (most viruses range in size from 10 to 300 or $400 \mathrm{~nm}$, with a molecular weight of $>30 \mathrm{kDa}$ ). The final volume of each viral concentrate ranged from 400 to $800 \mathrm{ml}$.

Direct counts of viruses and cyanobacteria. Viruslike particles (VLP) were enumerated following the protocol described by Chen et al. (2001). Briefly, $300 \mu \mathrm{l}$ of the water sample was filtered onto a $0.02 \mu \mathrm{m}$ poresize $\mathrm{Al}_{2} \mathrm{O}_{3}$ Anodisc $25 \mathrm{~mm}$ membrane filter (Whatman) with approximately $15 \mathrm{kPa}$ vacuum. The viral sample was stained with $5 \times$ SYBR Gold solution (final concentration) for 15 min in the dark. The stained Anodisc filter was mounted on a glass slide with a drop of immersion oil and a cover slip. The viral-like particles were then counted under blue excitation (485 nm) on a Zeiss Axioplan (Zeiss) epifluorescence microscope using $63 \times$ Antiflex Neoflua oil object-lens. The number of cyanobacteria in a water sample was determined with the protocol described by Waterbury et al. (1986). Briefly, 3 to $5 \mathrm{ml}$ of water sample was filtered onto a $0.2 \mu \mathrm{m}$ pore-size $25 \mathrm{~mm}$ black polycarbonate membrane filter (Osmonics). The cells were enumerated under green excitation (528 to $553 \mathrm{~nm}$ ) light using a Nikon Eclipse E400 (Nikon) epifluorescence microscope with a 100x plan oil object-lens. At least 200 viral particles or unicellular cyanobacterial cells per sample were counted.

Plaque assay. To enumerate cyanophages that infect Chesapeake Bay Synechococcus spp., a plaque assay was developed using Synechococcus sp. CB0101 isolated from the bay. Among many Synechococcus strains isolated from the bay, CB0101 was the most sensitive to viral infection. Strain CB0101 also represented a common genotype in the Synechococcus community, as revealed by RuBisCO gene sequences (Chen et al. unpubl. data). Strain CB0101 was grown in SN medium (Waterbury \& Willey 1988) of $12 \%$ and 22 to $24^{\circ} \mathrm{C}$, with $900 \mu \mathrm{M} \mathrm{NaNO}$ as a nitrogen source and was incubated at a light intensity of 20 to $30 \mu \mathrm{E} \mathrm{m} \mathrm{m}^{-2} \mathrm{~s}^{-1}$ and a light:dark cycle of 16:8 h. The pour-plating procedure for plaque assay followed the protocol described by Brahamsha (1996). For each plate, $100 \mu \mathrm{l}$ of viral concentrate was screened against CB0101, and triplicate plates were analyzed for each sample.

PCR amplification. The oligonucleotide primers CPS1 and CPS8 (Zhong et al. 2002) were used to 
amplify ca. 592 bp fragments from cyanomyoviruses. PCR amplification followed the protocol described by Zhong et al. (2002), except that the annealing temperature was increased to $46^{\circ} \mathrm{C}$ to increase PCR-specificity. We tested annealing temperatures ranging from 36 to $52^{\circ} \mathrm{C}$, and found that $46^{\circ} \mathrm{C}$ was the optimal temperature to avoid non-specific amplification. PCR product was examined by electrophoresis in $2 \%$ agarose gels stained with ethidium bromide. Gel images were captured and analyzed using the Kodak EDAS 290 gels-documentation system (Eastman Kodak).

Clone library construction. PCR amplicons from each VC were purified by using the Wizard PCR Prep DNA purification system (Promega). The purified DNA fragments were cloned into the pGEM-T easy cloning vector (Promega) and then transformed into JM109 competent cells (Promega) according to the manufacturer's instructions. Positive clones (white colonies) were picked randomly and transferred onto a new agar plate for further use.

Restriction fragment length polymorphism (RFLP) analysis. To avoid redundant sequencing, g20 clones amplified from 4 Chesapeake Bay virus communities were pre-screened with RFLP. About 60 positive clones from each clone library were randomly selected, and the plasmid inserts were PCR-amplified with vectorspecific primers T7 (5'-TAATACGACTCACTATAGG GCGA-3') and SP6 (5'-ATTTAGGTGACACTATAG-3') along with Taq DNA polymerase (Promega). PCR amplification cycles involved 3 min initial denaturation at $94^{\circ} \mathrm{C}$, followed by 35 cycles of $94^{\circ} \mathrm{C}$ for $1 \mathrm{~min}, 56^{\circ} \mathrm{C}$ for $1 \mathrm{~min}, 72^{\circ} \mathrm{C}$ for $2 \mathrm{~min}$, and a $5 \mathrm{~min}$ final extension at $72^{\circ} \mathrm{C}$. Once it was confirmed that a clone contained an insert of appropriate size (ca. $772 \mathrm{bp}$ ), the insert was subjected to RFLP analysis. Appropriate inserts were confirmed for 44 clones from Inner Harbor, 46 clones from Stn 908, 42 clones from Stn 818 and 48 clones from Stn 707. The commonly used restriction enzymes HaeIII (GG'CC) and RsaI (GT'AC) (Promega) for TRFLP analysis were used to digest the PCR products, and their resolutions were compared in a preliminary trial. RsaI yielded more RFLP patterns among tested clones than HaeIII (data not shown), and therefore RsaI was chosen to digest PCR products in the subsequent RFLP and T-RFLP analyses. A subsample (10 $\mu$ l) from each PCR mixture was digested with $5 \mathrm{U}$ RsaI in $1 \times$ buffer $\mathrm{C}$ (Promega) at $37^{\circ} \mathrm{C}$ overnight in a final reaction volume of $25 \mu \mathrm{l}$. Digested DNA was separated by $2 \%$ agarose gel electrophoresis as described above. The resulting RFLP patterns were examined and compared visually.

Sequencing and phylogenetic analysis. Representative clones (8 from Inner Harbor, 3 from Stn 908, 1 from Stn 818, 3 from Stn 707) that could be distinguished by
RFLP analysis were sequenced. The plasmid inserts from selected clones were PCR-amplified with vectorspecific Primers T7 and SP6 using Expand ${ }^{\mathrm{TM}}$ high fidelity DNA polymerase (Roche) under the conditions described above. The purified DNA from each representative genotype was sequenced bi-directionally with Primers T7 and SP6 using the ABI model 310 automated DNA sequencer (Applied Biosystems). Sequence alignment and phylogenetic analysis were performed using the Mac Vector 7.1 program (GCG). Pairwise alignment was calculated by using Blosum30 as matrix, with an open-gap penalty of 10.0 and an extended gap penalty of 0.1 . The phylogenetic tree was constructed using the neighbor-joining method based on ca. 197 amino acid residues inferred from their nucleotide sequence alignment with $\mathrm{T} 4$ as the outgroup. The protein distances were determined by the Poisson-correction method.

T-RFLP analysis. To obtain rapid fingerprintings of cyanomyovirus communities, CPS1 and 5' hex-labeled CPS8 primers were used for T-RFLP analysis, under the same PCR conditions described above. Purified PCR products were digested with RsaI overnight at $37^{\circ} \mathrm{C}$. Each $20 \mu \mathrm{l}$ digestion mixture contained ca. 300 ng PCR products, 5 U RsaI enzyme and acetylated BSA (final concentration $0.1 \mathrm{mg} \mathrm{ml}^{-1}$ ), as recommended by the manufacturer (Promega). The digested DNA was precipitated with a $0.1 \mathrm{vol}$ of $3 \mathrm{M}$ sodium acetate and $2.0 \mathrm{vol} 95 \%$ ethanol, followed by centrifugation at $16000 \times g$ for $20 \mathrm{~min}$. The DNA pellet was washed with $75 \%$ ethanol, dried, and resuspended in a mixture of $12 \mu \mathrm{l}$ deionized formamide and $0.5 \mu \mathrm{l}$ internal lane standard 600 (asymmetrically labeled with carboxy-x-rhodamine; Promega). Fluorescently labeled terminal restriction fragments (T-RFs) were sizeseparated on an ABI 310 automated sequencer (Applied Biosystems). T-RFLP profiles were generated and analyzed using GENESCAN 2.1 software (Applied Biosystems). The size, in basepairs, of T-RFs was analyzed by comparison with the internal standard using the Local Southern Method, GeneScan 2.1 software (Applied Biosystems). For each viral concentrate, a minimum of 2 samples was analyzed. To avoid detection of primers and other uncertainties, T-RFs $<50 \mathrm{bp}$ and $>600 \mathrm{bp}$ were excluded from the analysis, and only peaks over a threshold of 50 units above background fluorescence were analyzed.

Computer-based predictions of the expected T-RFs from g20 gene sequences were performed using the Mac Vector 7.1 program (GCG). To calibrate bias between the predicted size and observed size, the TRFs of g20 amplicons from representative clones were examined individually. The model community constructed with these amplicons was used as a reference for the subsequent T-RFLP profile analysis. 

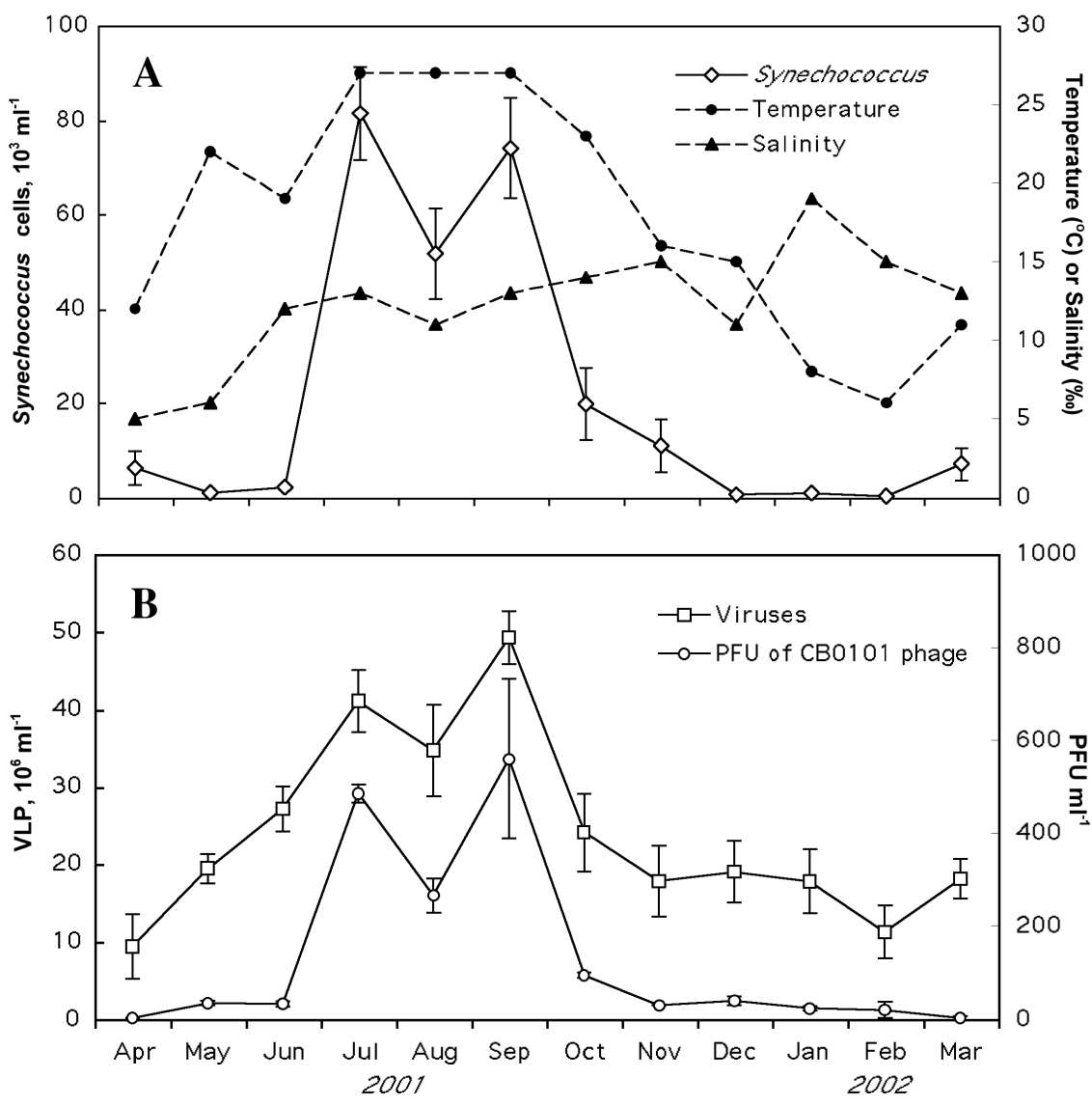

Fig. 2. A: Mean $( \pm \mathrm{SD})$ monthly variation in (A) Synechococcus cell density (cells $\mathrm{ml}^{-1}$ ), water temperature and salinity and (B) total VLP counts and Synechococcus phage titer at Pier 5, Baltimore Inner Harbor, from April 2001 to March 2002. PFU: plaque-forming units

Nucleotide sequence accession numbers. The nucleotide sequences determined in this study were deposited in the GenBank and assigned accession numbers from AY152732 to AY152746.

\section{RESULTS}

\section{Seasonal variation in Synechococcus spp. and their phages}

A strong seasonal variation in both Synechococcus and their phage abundance was observed in the Inner Harbor (Fig. 2A). Synechococcus density ranged from $2.6 \pm 0.5 \mathrm{SD} \times 10^{2}$ cells ml $^{-1}$ in February to $8.1 \pm 1.0 \times 10^{4}$ cells ml ${ }^{-1}$ in July (Fig. 2A), while the Synechococcus phage titer with strain CB0101 increased from a low 2.2 \pm 0 plaque-forming units (PFU) ml ${ }^{-1}$ in April to a high of $559.6 \pm 171.8 \mathrm{PFU} \mathrm{ml}^{-1}$ in September (Fig. 2B). Phage titers in the summer water were about 260 -fold higher than those in the winter (Fig. 2B). For observation of the diverse plaque morphotypes, we used Synechococcus CB0101. The diameters of plaques ranged from ca. $1 \mathrm{~mm}$ to $>1$ $\mathrm{cm}$. Both clear and turbid plaques with roughly circular or irregular shapes were present in the host bacterial lawn. More diverse plaque morphotypes and a wider range of plaque sizes were seen in the summer than in the winter In general, large and clear plaques ( $>5 \mathrm{~mm}$ in diameter) were dominant in warm seasons while only a few clear plaques (ca. $2 \mathrm{~mm}$ in diameter) were seen in cold seasons. Among 56 cyanophages recently isolated from the bay, approximately $60 \%$ of them tested positive with the g20 primers. During the course of this study the abundance of viral-like particles reached a maximum $\left(4.9 \pm 0.5 \times 10^{7} \mathrm{ml}^{-1}\right)$ in September and a minimum $\left(9.3 \pm 1.9 \times 10^{6} \mathrm{ml}^{-1}\right)$ in April. In general, the seasonal variation in Synechococcus cyanophages and total viral particles in the bay appeared to follow a similar pattern. Synechococcus cell density increased dramatically from June to July, and remained high $\left(>10^{4}\right.$ cells ml ${ }^{-1}$ ) until November. Correspondingly, the cyanophage titer and direct virus counts were low in the cold and high in the warm season (Fig. 2B). The temporal variation in Synechococcus and their phages appeared to be correlated with water temperature since salinity varied little with season in the Inner Harbor (Fig. 2A).

\section{g20 genotypes in the Chesapeake Bay}

The g20 gene fragments with ca. 592 bp (from 569 to $599 \mathrm{bp}$ ) were successfully amplified from Chesapeake Bay VCs. Among 180 randomly selected g20 clones, 15 distinguishable RFLP patterns were initially identified visually, and assigned as operational taxonomic units (OTUs) from OTU1 through OTU15. The relative abundance of these OTUs is summarized in Fig. 3. OTU2 and OTU6 were present in all $4 \mathrm{VC}$ samples from the Bay, with OTU6 being the most abundant (31\%). In the Inner Harbor VCs, 11 different RFLP patterns were observed, while 8, 8, and 7 RFLP types were found at Stns $908,818,707$ respectively (data not shown).

The representative clone sequences of the OTUs differed. Notably, only 1 (OTU12) of 15 OTUs was closely related to known cyanomyovirus isolates. The 


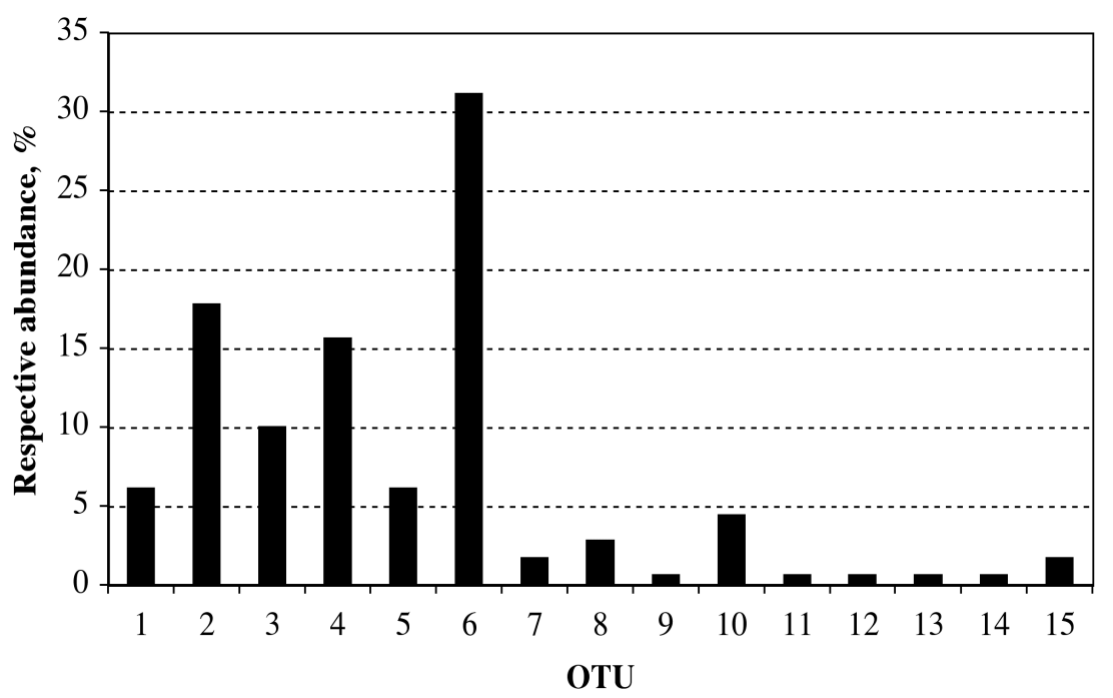

Fig. 3. Relative abundance (\%) of RFLP (restriction fragment length polymorphism) patterns digested by endonucleases RsaI at 4 stations (combined data) in the Chesapeake Bay, showing 15 different RFLP patterns, or OTUs identified among $180 \mathrm{~g} 20$ colonies recovered from the bay

g20 sequences recovered from Chesapeake Bay VCs appeared to be very diverse, and (using a cut-off value of 0.1 substitution per site) many formed unique clusters (Fig. 4). Clusters N1 to N4 contained only g20 clonal sequences recovered from the Bay. Cluster N1 (OTU6 and OTU15) and Cluster N4 (OTU1, 7 and 10), which accounted for $45 \%$ of 180 clones, were unique and significantly distant from all currently known g20 sequences. Cluster N2 (comprising OTU2, 4, 5, 8, 13 and 14), which accounted for $42 \%$ of 180 clones, could be related to the SE38 clone found in Skidaway Estuary. Cluster N3, which consisted of OTU3 and OTU9, was most closely related to a Sargasso Sea deep chlorophyll maximum clone (SS4705). OTU12 had a $>97 \%$ amino acid sequence similarity to SE34 (Skidaway Estuary clone), and was the only one that could be clustered with the known cyanomyovirus isolates. OTU11 was quite unique, and therefore not grouped with any cluster of isolates. In general, the vast majority of g20 sequences recovered from the Chesapeake Bay were unique and not closely related to currently known cyanomyovirus isolates.

\section{Cyanomyovirus population dynamics}

To identify the T-RFLP peaks using known g20 sequences, the predicted T-RFs of the representative g20 sequences were analyzed (Table 2). Table 2 shows 46 representative sequences chosen from more than 200 sequences of g20 gene in the GenBank and analyzed for possible T-RF patterns by computer analysis. Among
46 g20 representatives which included 15 OTUs, 10 cyanomyovirus isolates and 21 environmental clones, 20 unique T-RFs were identified with computer simulation of restriction enzyme RsaI. The T-RFs of SS4019 and OTU10 contained 4 and 27 bp respectively, and were therefore excluded from the analysis because of their small size (Table 2). The observed and predicted T-RFs of 15 OTUs are compared in Table 2 . There were 8 unique T-RFs generated from 15 representative OTUs clones. Except for OTU9, for which the observed T-RF was $8 \mathrm{bp}$ shorter than the predicted size (144 vs 152 bp), all other OTUs observed had T-RFs that matched well with the predicted size $( \pm 5 \mathrm{bp})$. The T-RFLP profile of this model community was therefore used as a reference for the subsequent analysis of spatial and temporal T-RFLP profiles of natural viral communities from the Chesapeake Bay.

Spatial distribution of cyanomyovirus population

The T-RFLP profiles from the Inner Harbor and the 3 stations in the Chesapeake Bay were strikingly similar (Fig. 5) even though the salinities at these sites ranged from 18 to $29 \%$ (Table 1). All OTUs differentiated by TRFLP could be detected in the spatial profile. Compared with the model community-profile consisting of $8 \mathrm{~T}$-RFs, more peaks (ca. 10 peaks on average) were present in the spatial profile. However, the relative abundances (as reflected by peak heights) of individual T-RFs varied from station to station in the spatial profile.

\section{Temporal T-RFLP profile of cyanomyovirus populations in Inner Harbor}

PCR amplification for T-RFLP analysis was mostly successful for samples collected monthly, except for the winter samples. It was not possible to obtain a g20 amplification from VCs collected in April and May 2001 or in February, April and May 2002 (data not shown). Although a g20 amplification was obtained for VC prepared in March 2001, its T-RFLP profile was poorly resolved. Therefore, only 9 T-RFLP profiles were successfully achieved for samples with positive g20 amplifications. At least 25 T-RFs could be differentiated in the temporal profile, indicating the diverse g20 genotypes present in the bay. In total, 18 peaks 
matching with predicted T-RFs (Table 2) were all observed in the temporal profile. In contrast to spatial profiles, the temporal T-RFLP profiles of 9 different months exhibited dramatic variation in genetic diversity (Fig. 6). About 12 major T-RFs were observed between July and September 2001, while only 3 major T-RFs were detected in January 2002. Correspond- ingly, the abundance of both the host Synechococcus and their phage titers (as determined by plaque assay using strain CB0101) reached maximum levels from July to September at a mean water temperature of $27^{\circ} \mathrm{C}$ and a salinity that varied only over a narrow range (ca. 11 to $13 \%$ ) during this period (Fig. 2A). In general, more T-RFs were seen during summer time

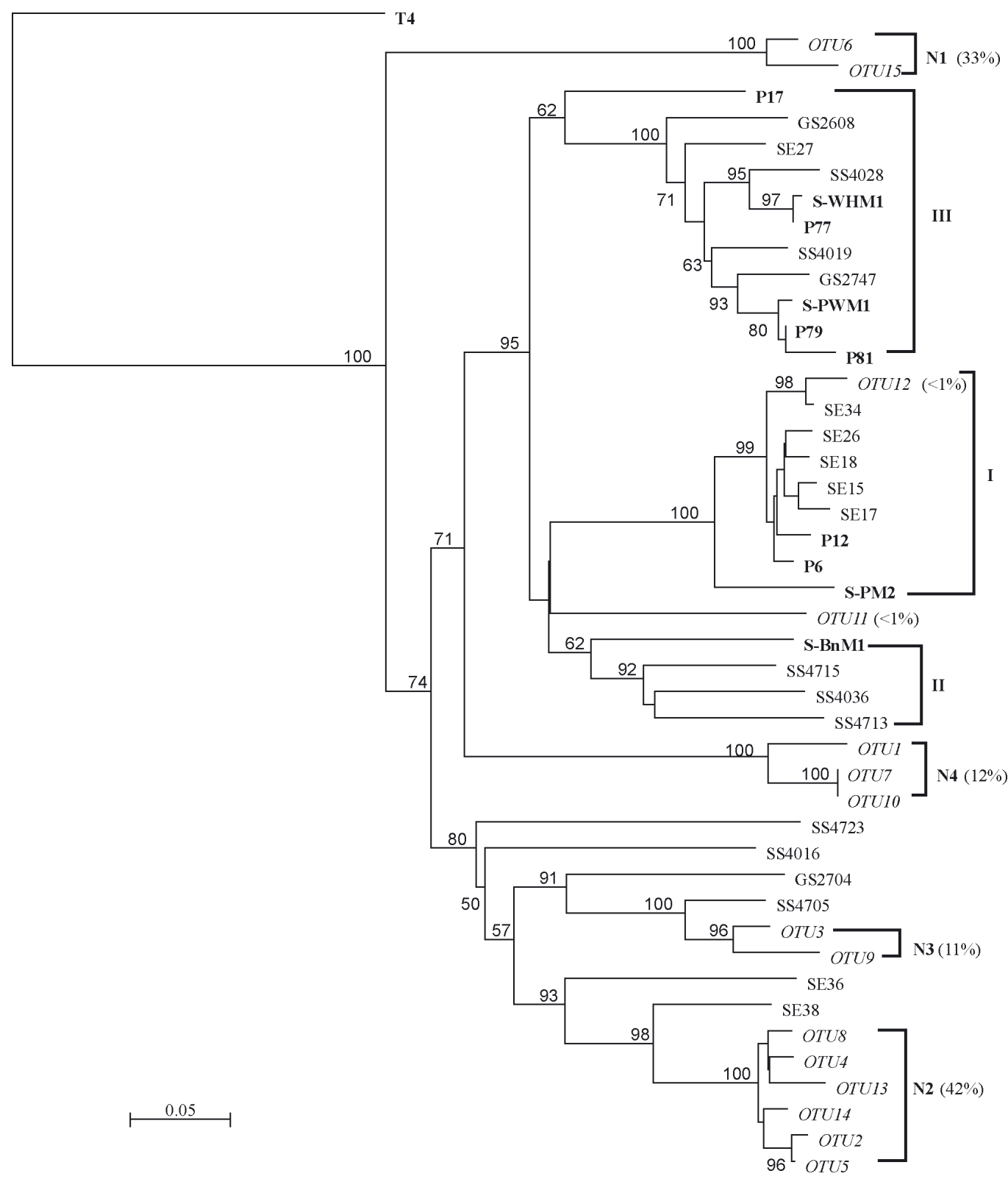

Fig. 4. Phylogenetic affiliation of Chesapeake Bay g20 genotypes (OTU1 to OTU15), showing cyanomyovirus isolates (bold-face) and representative g20 clones from various natural environments studied previously (Zhong et al. 2002). Values in parentheses: frequency of respective OTU (as \% of 180 clones studied). Tree was constructed using neighbor-joining method with Poisson correction based on ca. 197 amino acid residue sequence alignments, with T4 as an outgroup. Bootstrap values were generated with 1000 replicates; values $<50 \%$ not shown. Scale bar represents 0.05 substitutions per site. Clusters I-III were based on the protocol of Zhong et al. (2002); Clusters N1-N4 include only those clone sequences recovered from the Chesapeake Bay (i.e <0.1 substitutions per site) 
(from July to September 2001) than at other seasons, while T-RFLP patterns in August and September 2001 were most similar to each other. Notably, the T-RFs of ca. 480 bp (as represented by OTU 2, 4, and 5 in the spatial profile for November 2000) were missing from the temporal profile from June 2001 to March 2002.

\section{DISCUSSION}

The unique but diverse composition of the cyanomyovirus population in the Chesapeake Bay was revealed by the g20 gene clone sequences and subsequent $\mathrm{T}$ RFLP analysis. It has been reported that composition

Table 2. Samples, terminal restriction fragment (T-RF) size (bp) of g20 gene sequences after digestion with RsaI, hosts, isolation locations and literature sources in present study. nd: no data

\begin{tabular}{|c|c|c|c|c|}
\hline \multirow[t]{2}{*}{ Sample } & \multicolumn{2}{|c|}{ T-RF size } & \multirow[t]{2}{*}{ Host and/or isolation location } & \multirow[t]{2}{*}{ Source } \\
\hline & Predicted & Observed & & \\
\hline \multicolumn{5}{|c|}{ Chesapeake Bay clones } \\
\hline OTU1 & 140 & 140 & Inner Harbor & This study \\
\hline OTU2 & 485 & 481 & Inner Harbor & This study \\
\hline OTU3 & 221 & 216 & Inner Harbor & This study \\
\hline OTU4 & 485 & 480 & Inner Harbor & This study \\
\hline OTU5 & 485 & 480 & Inner Harbor & This study \\
\hline OTU6 & 592 & 592 & Stn 707 & This study \\
\hline OTU7 & 401 & 405 & Stn 908 & This study \\
\hline OTU8 & 346 & 342 & Stn 707 & This study \\
\hline OTU9 & 152 & 144 & Stn 908 & This study \\
\hline OTU10 & 27 & nd & Inner Harbor & This study \\
\hline OTU11 & 266 & 262 & Inner Harbor & This study \\
\hline OTU12 & 592 & 588 & Inner Harbor & This study \\
\hline OTU13 & 347 & 343 & Stn 707 & This study \\
\hline OTU14 & 346 & 342 & Stn 818 & This study \\
\hline OTU15 & 592 & $586-592$ & Stn 908 & This study \\
\hline \multicolumn{5}{|c|}{ Cyanomyovirus isolates } \\
\hline P6 & 592 & nd & WH7805; Dauphin Island, Ala & Lu et al. (2001) \\
\hline P12 & 592 & nd & WH8101; Sayll Estuary, Ala & Lu et al. (2001) \\
\hline P17 & 457 & nd & WH7803; Qingdao Coast, China & Lu et al. (2001) \\
\hline P77 & 150 & nd & WH8007; Altamaha River Estuary, Ga & Lu et al. (2001) \\
\hline P79 & 404 & nd & WH7805; Satilla River Estuary, Ga & Lu et al. (2001) \\
\hline P81 & 404 & nd & WH7805; Altamaha River Estuary, Ga & Lu et al. (2001) \\
\hline S-PWM1 & 404 & nd & WH7803; Gulf of Mexico & Suttle \& Chan (1993) \\
\hline S-PM2 & 592 & nd & WH7803; Plymouth, UK & Wilson et al. (1993) \\
\hline S-WHM1 & 150 & nd & WH7803; Woods Hole, Mass & Wilson et al. (1993) \\
\hline S-BnM1 & 115 & nd & WH7803; Bergen, Norway & Wilson et al. (1993) \\
\hline \multicolumn{5}{|c|}{$\begin{array}{l}\text { Representative clones from } \\
\text { various environments }\end{array}$} \\
\hline SE1 & 592 & nd & Skidaway, Ga $\left(31^{\circ} 59^{\prime} \mathrm{N}, 81^{\circ} 01^{\prime} \mathrm{W}\right)$ & Zhong et al. (2002) \\
\hline SE15 & 106 & nd & Skidaway, Ga $\left(31^{\circ} 59^{\prime} \mathrm{N}, 81^{\circ} 01^{\prime} \mathrm{W}\right)$ & Zhong et al. (2002) \\
\hline SE17 & 592 & nd & Skidaway, Ga $\left(31^{\circ} 59^{\prime} \mathrm{N}, 81^{\circ} 01^{\prime} \mathrm{W}\right)$ & Zhong et al. (2002) \\
\hline SE18 & 592 & nd & Skidaway, Ga $\left(31^{\circ} 59^{\prime} \mathrm{N}, 81^{\circ} 01^{\prime} \mathrm{W}\right)$ & Zhong et al. (2002) \\
\hline SE26 & 592 & nd & Skidaway, Ga $\left(31^{\circ} 59^{\prime} \mathrm{N}, 81^{\circ} 01^{\prime} \mathrm{W}\right)$ & Zhong et al. (2002) \\
\hline SE27 & 162 & nd & Skidaway, Ga $\left(31^{\circ} 59^{\prime} \mathrm{N}, 81^{\circ} 01^{\prime} \mathrm{W}\right)$ & Zhong et al. (2002) \\
\hline SE34 & 592 & nd & Skidaway, Ga $\left(31^{\circ} 59^{\prime} \mathrm{N}, 81^{\circ} 01^{\prime} \mathrm{W}\right)$ & Zhong et al. (2002) \\
\hline SE36 & 152 & nd & Skidaway, Ga $\left(31^{\circ} 59^{\prime} \mathrm{N}, 81^{\circ} 01^{\prime} \mathrm{W}\right)$ & Zhong et al. (2002) \\
\hline SE38 & 312 & nd & Skidaway, Ga $\left(31^{\circ} 59^{\prime} \mathrm{N}, 81^{\circ} 01^{\prime} \mathrm{W}\right)$ & Zhong et al. (2002) \\
\hline GS2608 & 162 & nd & Gulf Stream $\left(37^{\circ} 19^{\prime} \mathrm{N}, 71^{\circ} 37^{\prime} \mathrm{W}\right)$ & Zhong et al. (2002) \\
\hline GS2704 & 312 & nd & Gulf Stream $\left(36^{\circ} 24^{\prime} \mathrm{N}, 71^{\circ} 20^{\prime} \mathrm{W}\right)$ & Zhong et al. (2002) \\
\hline GS2747 & 312 & nd & Gulf Stream $\left(36^{\circ} 24^{\prime} \mathrm{N}, 71^{\circ} 20^{\prime} \mathrm{W}\right)$ & Zhong et al. (2002) \\
\hline SS4016 & 592 & nd & Sargasso Sea $\left(28^{\circ} 53^{\prime} N, 65^{\circ} 04^{\prime} \mathrm{W}\right)$ & Zhong et al. (2002) \\
\hline SS4019 & 4 & nd & Sargasso Sea $\left(28^{\circ} 53^{\prime} N, 65^{\circ} 04^{\prime} \mathrm{W}\right)$ & Zhong et al. (2002) \\
\hline SS4028 & 312 & nd & Sargasso Sea $\left(28^{\circ} 53^{\prime} N, 65^{\circ} 04^{\prime} \mathrm{W}\right)$ & Zhong et al. (2002) \\
\hline SS4036 & 592 & nd & Sargasso Sea $\left(28^{\circ} 53^{\prime} N, 65^{\circ} 04^{\prime} \mathrm{W}\right)$ & Zhong et al. (2002) \\
\hline SS4705 & 162 & nd & Sargasso Sea $\left(34^{\circ} 43^{\prime} N\right.$, $\left.68^{\circ} 07^{\prime} \mathrm{W}\right)$ & Zhong et al. (2002) \\
\hline $\mathrm{SS} 4713$ & 315 & nd & Sargasso Sea $\left(34^{\circ} 43^{\prime} N\right.$, $\left.68^{\circ} 07^{\prime} \mathrm{W}\right)$ & Zhong et al. (2002) \\
\hline SS4715 & 457 & nd & Sargasso Sea $\left(34^{\circ} 43^{\prime} N\right.$, $\left.68^{\circ} 07^{\prime} \mathrm{W}\right)$ & Zhong et al. (2002) \\
\hline $\mathrm{SS} 4716$ & 485 & nd & Sargasso Sea $\left(34^{\circ} 43^{\prime} N\right.$, $\left.68^{\circ} 07^{\prime} \mathrm{W}\right)$ & Zhong et al. (2002) \\
\hline SS4723 & 159 & nd & Sargasso Sea $\left(34^{\circ} 43^{\prime} N, 68^{\circ} 07^{\prime} \mathrm{W}\right)$ & Zhong et al. (2002) \\
\hline
\end{tabular}


Terminal restriction fragment length (bases)

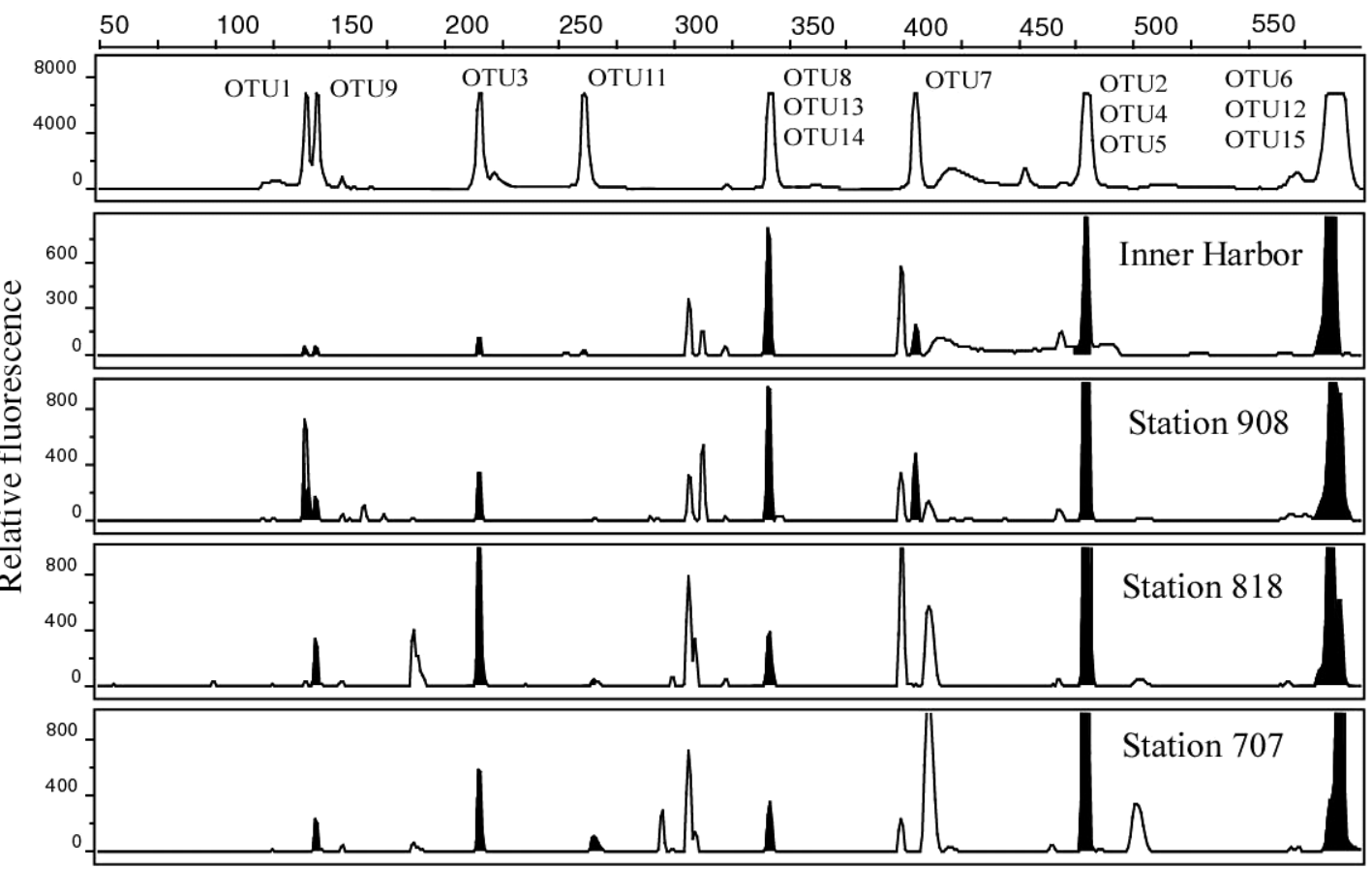

Fig. 5. Spatial T-RFLP profile of g20 genes at Chesapeake Bay stations (November 1-3, 2000). Black peaks: T-RFs that match expected sizes in Table 2

and structure of natural cyanophage communities in the estuary differ from those in the open ocean when determined by g20 gene sequences (Zhong et al. 2002). About $43 \%$ of g20 OTUs (OTUs $2,45,8,12,13$ and 14) in Chesapeake Bay clustered with the g20 clones recovered from Savannah Estuary, suggesting that cyanophages and perhaps their hosts in coastal estuaries share certain similarities in terms of community structures. Only a small percentage (11\%) of g20 OTUs (OTUs 3 and 9) in the bay appeared to be related to open-ocean g20 clones. The g20 sequences recovered from environmental samples appeared to be much more diverse than those of cyanomyovirus isolates. The majority of identified cyanomyoviruses infecting Synechococcus spp. were isolated from pink or oceanic strains (Suttle \& Chan 1993, Waterbury \& Valois 1993, Suttle 2000). Recent studies in our laboratory suggested that Synechococcus communities in the bay are more diverse than those in coastal and openocean waters, as revealed by the $r b c L$ gene phylogeny (Chen et al. unpubl. data). It is possible that the composition of host Synechococcus populations in the bay is different from that in the oceanic water. Further characterization of cyanophages that infect more Chesapeake Bay-Synechococcus strains may shed light on the g20 clonal sequences recovered from the Inner Harbor and Chesapeake Bay. In addition, we cannot rule out that some of the g20 environmental clones may originate from phages that infect other bacteria. Much more effort is needed to characterize more g20 sequences from phages that infect different Synechococcus trains and other marine bacteria.

In the Chesapeake Bay samples, approximately 9 to 25 T-RFLP peaks or genotypes were visible for each sample. Previous DGGE analysis of g20 gene differentiated 2 to 10 genotypes in each viral concentrate samples in the Atlantic Ocean (Wilson et al. 1999, 2000). It is difficult to compare the data resulted from DGGE and T-RFLP because (1) the samples were from different environments (estuary vs open-ocean); (2) PCR primers and amplicon length (ca. 592 bp vs ca. 160 bp) differed; and (3) detection methods for DGGE bands and T-RFLP peaks differed. The observation of many unpredicted T-RFs in both the spatial and temporal TRFLP profiles also implied the possible presence of previously unidentified g20 genotypes in the bay. The difference between expected and observed T-RFs together with some of the unpredicted T-RFs in the TRFLP profiles could result from partial or unspecific restriction digestion and/or bias introduced during PCR amplification. This is indeed the inherent pitfall of the T-RFLP technique, which heavily relies on PCR amplification accuracy and the efficiency of restriction enzymes. Therefore, care must been taken to optimize preparation of T-RFLP samples in order to minimize these uncertainties. In this study, a minimum of 2 sam- 
ples were analyzed and compared for each VC. Analysis and comparison between replicates of the same sample are necessary to obtain statistically robust $\mathrm{T}$ RFLP data.

VC samples were used for both T-RFLP analysis and plaque assay. This may have led to underestimations of natural viral titers due to the losses of viruses and/or their infectivity during the viral concentration proccesses. Failure to amplify the g20 gene from 5 VCs collected in February (2002), April and May (2001 and 2002) could have been due to the low titers of cyanophages during at these times. The Synechococcus cell density and CB0101 cyanophage titers were very low during these months (Fig. 2). Other

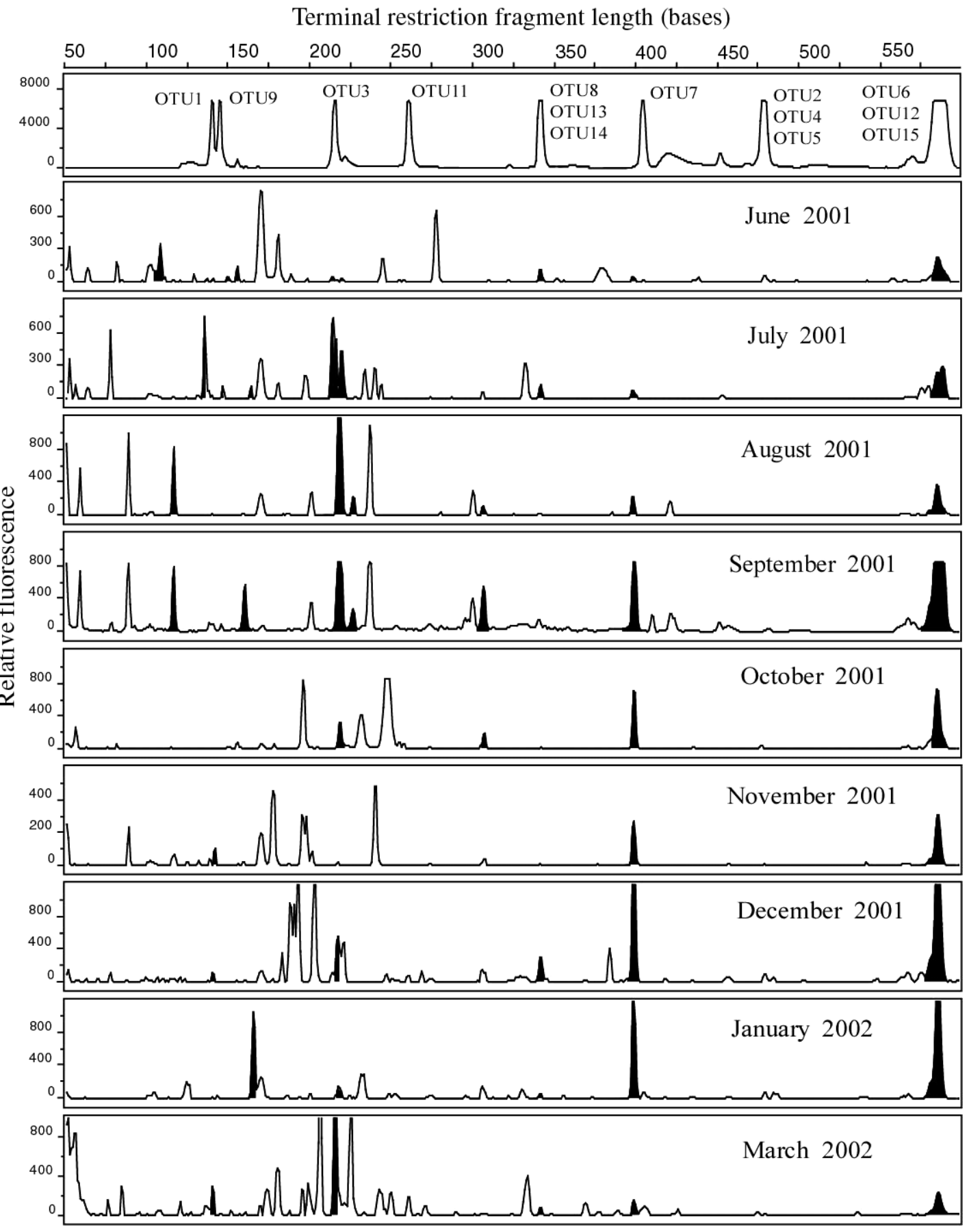

Fig. 6. Temporal T-RFLP profile of cyanomyoviral g20 gene in Inner Harbor from June 2001 to March 2002. Black peaks: T-RFs that match expected sizes in Table 2 
studies in Woods Hole Harbor (Waterbury \& Valois 1993) and Tampa Bay (McDaniel et al. 2002) also found that both Synechococcus and their phages are most abundant in summer and least in winter. The abundance of infectious cyanophages is known to correlate directly and strongly with host concentrations rather than other environmental variables (Suttle 2000). For lytic virus production to occur, Synechococcus abundance must be at least $10^{3}$ to $10^{4} \mathrm{ml}^{-1}$ (Suttle \& Chan 1993, 1994). Therefore, low abundance $\left(<10^{3}\right.$ $\mathrm{ml}^{-1}$, this study) of host Synechococcus during winter and early spring could result in the production of few lytic cyanophages. In this study, a Chesapeake Bay Synechococcus strain CB0101 was chosen to provide host cells for plaque assay with the intention of better estimating cyanophage abundance in the bay. We compared the phage titers obtained using WH7803 (which is susceptible to a broad spectrum of cyanophages and has been used widely in previous studies) to those obtained with CB0101 with the same VC samples. Both yielded a similar range of phage titers, except that in 2 months (November and December 2001), more phage titers could be obtained with WH7803 (data not shown). Nevertheless, seasonal variation in cyanophage titers ( $>2$ orders of magnitude) is consistent with results of previous studies (Waterbury \& Valois 1993).

The similar T-RFLP patterns in community fingerprints observed at 4 stations in the bay suggest that there was no significant variation in genetic diversity of the cyanomyovirus communities in the surface water of the bay in November 2000. In contrast, the dramatic temporal change in g20 gene T-RFLP patterns observed in this study suggested that the cyanomyophage community could be more diverse in summer than in winter. The DGGE profiles of the bacterial communities from the surface water column in the bay also demonstrated a stronger seasonal than spatial pattern (Kan \& Chen unpubl. data).

The significant seasonal changes in both cyanophage titers and their genetic diversity in the bay appeared to be correlated with changes in the host populations of Synechococcus spp. Maximum cyanophage diversity was also observed when Synechococcus abundance reached its annual maximum. This observation is also consistent with a previous study in the Atlantic Ocean (Wilson et al. 2000). The dynamic interaction between cyanophage and Synechococcus communities in the bay suggests that cyanophages could play an important role in temporal regulation of Synechococcus biomass and population structure. Further investigation of the spatial distribution of both cyanophages and their hosts across the bay in different seasons would help us to better understand the geographical variation in cyanophage populations.
Here, using the g20 gene, we demonstrated for the first time that T-RFLP of the g20 gene can be used as a rapid fingerprinting method to explore the population dynamics of a specific group of viruses in the aquatic environment. Currently, we are developing PCR primers that are specific for Synechococcus spp. based on the RuBisCO gene. It is expected that a T-RFLP- or DGGEbased method could also be used to obtain fingerprints of Synechococcus populations. This would allow us to study the co-variation and co-evolution of the cyanophage and host cyanobacterial communities in natural aquatic environments.

Acknowledgements. This work was supported by grants from the National Science Foundation (OCE-9730602, OCE0049098 and MCB-0132070). We thank the crew of the RV 'Cape Henlopen'. We also thank J. Sheng and J. J. Kan for collecting viral concentrates and helpful discussion, and 2 anonymous reviewers for their valuable comments on an earlier version of the manuscript. We also thank J. Enticknap for her careful proofreading of this manuscript. Contribution No. 601 from the Center of Marine Biotechnology, University of Maryland Biotechnology Institute.

\section{LITERATURE CITED}

Ackermann HW, DuBow MS (1987) Viruses of prokaryotes, CRC Press, Boca Raton, FL

Avaniss-Aghajani E, Jones K, Chapman D, Brunk C (1994) A molecular technique for identification of bacteria using small subunit ribosomal RNA sequences. Biotechniques 17:144-149

Bergh O, Borsheim KY, Bratbak G, Heldal M (1989) High abundance of viruses found in aquatic environments. Nature 340:467-468

Brahamsha B (1996) A genetic manipulation system for oceanic cyanobacteria of the genus Synechococcus. Appl Environ Microbiol 62:1747-1751

Bratbak G, Thingstad F, Heldal M (1994) Viruses and the microbial loop. Microb Ecol 28:209-221

Chen F, Suttle CA, Short SM (1996) Genetic diversity in marine algal virus communities as revealed by sequence analysis of DNA polymerase genes. Appl Environ Microbiol 62:2869-2874

Chen F, Lu JR, Binder B, Hodson RE (2001) Enumeration of viruses in aquatic environments using SYBR gold stain: application of digital image analysis and flow cytometer. Appl Environ Microbiol 67:539-545

Fuhrman JA (1999) Marine viruses and their biogeochemical and ecological effects. Nature 399:541-547

Fuhrman JA, Suttle CA (1993) Viruses in marine planktonic systems. Oceanography 6:51-63

Fuller NJ, Wilson WH, Joint IR, Mann NH (1998) Occurrence of a sequence in marine cyanophages similar to that of T4 g20 and its application to PCR-based detection and quantification techniques. Appl Environ Microbiol 64:2051-2060

Kitts CL (2001) Terminal restriction fragment patterns: a tool for comparing microbial communities and assessing community dynamics. Curr Issues Intest Microbiol 2:17-25

Li WKW (1994) Primary production of prochlorophytes, cyanobacteria, and eukaryotic ultraphytoplankton: measurements from flow cytometric sorting. Limnol Oceanogr 39: $169-175$ 
Liu WT, Marsh TL, Cheng H, Forney LJ (1997) Characterization of microbial diversity by determining terminal restriction fragment length polymorphisms of genes encoding 16S rRNA. Appl Environ Microbiol 63:4516-4522

Lu J, Chen F, Hodson RE (2001) Distribution, isolation, host specificity, and diversity of cyanophages infecting marine Synechococcus spp. in the Georgia river estuaries. Appl Environ Microbiol 67:3285-3290

Marsh TL (1999) Terminal restriction fragment length polymorphism (T-RFLP): an emerging method for characterizing diversity among homologous populations of amplicons. Curr Opin Microbiol 2:323-327

Martin E, Benson R (1988) Phages of cyanobacteria. In: Calendar R (ed) The bacteriophages, Vol 2. Plenum Press, New York, p 607-645

McDaniel L, Houchin LA, Williamson SJ, Paul JH (2002) Plankton blooms: lysogeny in marine Synechococcus. Nature 415:496

Muyzer G (2000) Genetic fingerprinting of microbial communities - present status and future perspectives. In: Bell CR, Brylinsky M, Johnson-Green P (eds) Microbial Biosystems: New Frontiers. Proc 8th Int Symp Microb Ecol. Halifax, Canada. Atlantic Canada Society for Microbial Ecology, Kentville, p 503-512

Muyzer G, de Waal EC, Uitterlinden AG (1993) Profiling of complex microbial populations by denaturing gradient gel electrophoresis analysis of polymerase chain reactionamplified genes coding for 16S rRNA. Appl Environ Microbiol 59:695-700

Osborn AM, Moore ERB, Timmis KN (2000) An evaluation of terminal-restriction fragment length polymorphism ( $\mathrm{T}$ RFLP) analysis for the study of microbial community structure and dynamics. Environ Microbiol 2:39-50

Paul JH (1999) Microbial gene transfer: an ecological perspective. J Mol Microbiol Biotechnol 1:45-50

Proctor LM, Fuhrman JA (1990) Viral mortality of marine bacteria and cyanobacteria. Nature 343:60-62

Safferman RS, Cannon RE, Desjardins PR, Gromov BV, Haselkorn R, Sherman LA, Shilo M (1983) Classification and nomenclature of viruses of cyanobacteria. Intervirology 19:61-66

Suttle CA (2000) Cyanophages and their role in the ecology of cyanobacteria. In: Whitton BA, Potts M (eds) The ecology of cyanobacteria: their diversity in time and space. Kluwer Academic Publishers, Boston, p 563-589

Suttle CA, Chan AM (1993) Marine cyanophages infecting oceanic and coastal strains of Synechococcus: abundance, morphology, cross-reactivity and growth characteristics. Mar Ecol Prog Ser 92:99-109

Suttle CA, Chan AM (1994) Dynamics and distribution of

Editorial responsibility: Gunnar Bratbak,

Bergen, Norway cyanophages and their effect on marine Synechococcus spp. Appl Environ Microbiol 60:3167-3174

Suttle CA, Chan AM, Cottrell MT (1990) Infection of phytoplankton by viruses and reduction of primary productivity. Nature 347:467-469

Thingstad TF, Heldal M, Bratbak G, Dundas I (1993) Are viruses important partners in pelagic food webs? TREE 8: 209-213

Waterbury JB, Valois FW (1993) Resistance to co-occurring phages enables marine Synechococcus communities to coexist with cyanophages abundant in seawater. Appl Environ Microbiol 59:3393-3399

Waterbury JB, Willey JM (1988) Isolation and growth of marine planktonic cyanobacteria. Methods Enzymol 167:100-105

Waterbury JB, Watson SW, Valois FW, Franks DG (1986) Biological and ecological characterization of the marine unicellular cyanobacterium Synechococcus. Can Bull Fish Aquat Sci, Toronto, p 71-120

Wilhelm SW, Suttle CA (1999) Viruses and nutrient cycles in the sea: viruses play critical roles in the structure and function of aquatic food webs. BioScience 49:781-788

Wilson WH, Joint IR, Carr NG, Mann NH (1993) Isolation and molecular characterization of five marine cyanophages propagated on Synechococcus sp. strain WH7803. Appl Environ Microbiol 59:3736-3742

Wilson WH, Nicholas JF, Joint IR, Mann NH (1999) Analysis of cyanophage diversity and population structure in a south-north transect of the Atlantic Ocean. Bull Inst Océanogr 19:209-216

Wilson WH, Nicholas JF, Joint IR, Mann NH (2000) Analysis of cyanophage diversity in the marine environment using denaturing gradient gel electrophoresis. In: Bell CR, Brylinsky M, Johnson-Green P (eds) Microbial biosystems: New Frontier. Proc 8th Int Symp Microb Ecol. Halifax, Canada. Atlantic Canada Society for Microbial Ecology, Kentville, p 565-570

Wommack KE, Colwell RR (2000) Virioplankton: viruses in aquatic ecosystems. Microbiol Mol Biol Rev 64:69-114

Wommack KE, Ravel J, Hill RT, Colwell RR (1999a) Population dynamics of Chesapeake Bay virioplankton: total community analysis using pulsed field gel electrophoresis. Appl Environ Microbiol 65:231-240

Wommack KE, Ravel J, Hill RT, Colwell RR (1999b) Hybridization analysis of Chesapeake Bay virioplankton. Appl Environ Microbiol 65:241-250

Zhong Y, Chen F, Wilhelm SW, Poorvin L, Hodson RE (2002) Phylogenetic diversity of marine cyanophage isolates and natural virus communities as revealed by sequences of viral capsid assembly protein gene g20. Appl Environ Microbiol 68:1576-1584

Submitted: May 30 2003; Accepted: September 11, 2003

Proofs received from author(s): January 21, 2004 